\title{
THE PRODUCT LIABILITY SYSTEM IN CHINA: RECENT CHANGES AND PROSPECTS
}

\author{
KRISTIE THOMAS*
}

\begin{abstract}
Following the enactment of the 2009 Tort Liability Law, the product liability system in China is largely complete. This article sketches the development of this system before outlining some of the main substantive provisions in force today and drawing comparisons between the Chinese approach and the US and European provisions. The Article will conclude that China's product liability system provides an interesting case study which enriches the study of global trends and norms in the product liability arena. In line with many other countries, particularly in the Asia-Pacific region, the main influence on China has been the EC Directive rather than the US model.
\end{abstract}

Keywords: China, civil law, consumers, product liability, tort.

\section{INTRODUCTION}

With the recent adoption of the 2009 Tort Liability Law (TLL) ${ }^{1}$ (in force from July 2010), it is timely to examine the development of the product liability regime in the People's Republic of China (PRC). ${ }^{2}$ This paper seeks to outline the evolution of product liability in modern China from the initial introduction of a rudimentary set of tortious principles in the 1980 s, to the more detailed provisions promulgated in the 1993 Product Quality Law and 1993 Consumer Rights and Interests Protection Law, and to the more recent changes wrought by the 2009 Tort Liability Law (TLL). These reforms must also be set against a background of

\footnotetext{
${ }^{*}$ Lecturer in Business Law, Nottingham University Business School, kristie.thomas@ nottingham.ac.uk.

${ }^{1}$ Zhonghua Renmin Gongheguo Qinquan Zerenfa, Tort Liability Law of the People's Republic of China (2009) < http://www.gov.cn/flfg/2009-12/26/content_1497435.htm >. English translation taken from 'PRC Tort Liability Law' (June 2010) China Law \& Practice.

${ }^{2}$ The topic of product liability laws in China has not thus far been covered in detail in English language scholarship with one notable exception: J Li, Law on Product Quality Control and Product Liability in China (William S Hein \& Co 2006).
} 
increasingly sophisticated Chinese consumers who are ever more willing to pursue their claims to court.

The evolution of the product liability system in China also needs to be set against a complex background of (over-)reliance on administrative remedies and multi-agency jurisdiction over defective products. Although these issues are not unique to China, they can also offer a useful perspective on the developing institutional capacity and regulatory norms in a country striving to move from a Socialist command economy to a modern economy driven by both exports and domestic demand. Both of these avenues for potential growth rely on product quality as a key factor and thus the development of a functional product liability system is crucial to secure the continued economic development of China in the future.

Further, examining the contemporary product liability system in China can illuminate aspects of the evolution of the wider Chinese legal system, such as the tensions between mediation and litigation as preferred methods of dispute resolution; the parallel tensions between civil liability and regulation via administrative means; and the emerging rule of law in China. Analysis of the Chinese product liability system can also contribute to existing debates on product liability on a global basis, including harmonization of product liability norms around the world, as well as the desirability (or otherwise) of such convergence; the increasingly blurred lines between the common law and civil law 'families' (and where East Asian legal systems fit into such a classification); and the twin dominance of the US model and systems based on the EC Directive as opposing models for developing product liability systems to emulate.

The TLL largely completed the formation of a modern product liability system which had been under construction for nearly 30 years. Although the TLL did not alter the pre-existing fundamental roots of the product liability system, it consolidated previous provisions on 
tortious liability, which were scattered throughout a range of laws, regulations and judicial interpretations, into an inclusive law with 12 chapters and a total of 92 Articles. In particular, the TLL increased the civil remedies available to consumers by introducing punitive damages, only previously available for certain product classes/categories, as well as mandating a universal warning and product recall system. Thus, the second part of this article will cover the background of product liability in China which culminated in the 2009 TLL and essentially aims to detail how and why the product liability regime developed as it did. This section will also contain some comments about how the Chinese experience compares to the development of product liability regimes in other jurisdictions, focusing on the US and Europe.

Next, the third part will discuss some of the most significant substantive provisions of the product liability system in China and draw comparisons with other product liability regimes around the world, in order to evaluate the Chinese system more systematically. In particular, reference will be made to the US product liability system post-Third Restatement ${ }^{3}$ and to countries adopting the 1985 EC Directive on Liability for Defective Products, ${ }^{4}$ in order to highlight to what extent the Chinese product liability regime is converging or diverging away from product liability norms in other jurisdictions. This section will focus on certain key elements of the product liability system, including: where the relevant rules can be found; whether the basis of liability is strict or based on fault; the remedies available including the potential availability or otherwise of punitive damages; and the mechanisms available for enforcement either by individual consumers or consumer bodies. The final section will draw these observations together to discuss what the Chinese product liability system can tell us more broadly about the general development of the Chinese legal system, the implications for

\footnotetext{
${ }^{3}$ Restatement of the Law, Third, Torts: Products Liability (American Law Institute 1998).

${ }^{4}$ Council Directive 85/374/EEC of 25 July 1985 on the Approximation of the Laws, Regulations and Administrative Provisions of the Member States concerning Liability for Defective Products [1985] OJ L 210, 29.
} 
product liability norms globally, as well as considering any enduring practical and political barriers to the operation of an effective product liability system in China.

\section{DEVELOPMENT OF PRODUCT LIABILITY IN CHINA}

Civil law matters have generally received scant attention throughout Chinese legal history. Civil law was largely ignored in imperial China and any tortious liability cases which did arise were largely handled under the criminal law, due to the emphasis on criminal law in the legal system overall at this time. ${ }^{5}$ Initial reform efforts began in the Chinese legal system broadly as the Qing dynasty was in its final stages, around the start of the twentieth century. Scholars looked primarily to Japan for guidance, which itself had been heavily influenced by the German Civil Code (BGB). This 'borrowing' from Japanese codes has been attributed to the similarities between China's legal history and the civilian tradition of codification, as well as Japan's obvious geographical proximity. Despite tort's inclusion in the early twentiethcentury Japan-inspired Qing Civil Code draft (Article 945) as qinquan xingwei (infringement of civil right), ${ }^{6}$ this draft was not implemented due to the Republican Revolution which took place in 1911.

Subsequently, the first Chinese civil code was promulgated from 1929 to 1930 and this code still forms the basis of the civil code in use in Taiwan today, although the modern version has been subject to various updates and amendments since $1930 .^{7}$ However, following the founding of the People's Republic of China in October 1949 by the Chinese Communist Party, all former laws were renounced on ideological grounds and thus, this preexisting comprehensive civil code was abandoned in mainland China. Although there were

\footnotetext{
${ }^{5}$ Y Lin, 'The Tort System in China' (1989) 52(3) Law and Contemporary Problems 143, 145.

${ }^{6}$ M Zhang, 'Tort Liabilities and Torts Law: The New Frontier of Chinese Legal Horizon' (2011) 10(4) Richmond Journal of Global Law and Business 423.

${ }^{7}$ Y Zhu, 'The Bases of Liability in Chinese Tort Liability Law: Historical and Comparative Perspectives' in L Chen and CH van Rhee (eds), Towards a Chinese Civil Code: Comparative and Historical Perspectives (Martinus Nijhoff 2012) 337-8.
} 
abortive attempts made to draft a civil code in $1954-56$ and $1962-64,{ }^{8}$ tort law largely stagnated from 1949 to the early 1980s with no centralized provisions on tort passed. China was not exceptional in this lack of legal protection for consumers and this deficiency was paralleled in other Socialist legal systems, ${ }^{9}$ resulting from a centrally planned economy firmly focused on industry. Not only did a lack of competition between enterprises contribute to a lack of incentives to improve product safety, but the notion of an individual as a consumer was also somewhat alien to Communist ideology. Indeed, claims by individual citizens against state-owned enterprises (SOEs) regarding defective products could even be viewed as claims against the State. Product quality in particular suffered as China's leaders focused almost exclusively on gross industrial output. ${ }^{10}$

However, the death of Mao Zedong and the subsequent return to power of Deng Xiaoping heralded the start of the modernization efforts in China known as the 'reform and openingup' period. As this era began from 1978 onwards, China recognized that economic reform efforts would need to be supported by a robust legal system in order to boost investor confidence. This echoes the Law and Development orthodoxy that a modern legal system which enforces contractual and property rights will necessarily promote the development of market forces and hence encourage economic growth. ${ }^{11}$ Thus, a draft civil code was circulated in 1982, which although it was not enacted, still proved influential and led to the passing of the PRC General Principles of Civil Law (GPCL) in $1986 .{ }^{12}$ Hence, the first major law to systematically introduce tort principles into the post-1949 Chinese legal system was

\footnotetext{
${ }^{8}$ Q He and X Yin, Zhonghua Renmin Gongheguo Min Fa Shi (History of the Civil Law in the PRC) (Fudan University Press 1999).

${ }^{9}$ M Sengayen, 'Product Liability: The Perspective of New Member Countries' in D Fairgrieve (ed), Product Liability in Comparative Perspective (CUP 2005) 259.

${ }^{10}$ EJ Epstein, 'Tortious Liability for Defective Products in the People's Republic of China' (1988) 2 Journal of Chinese Law 285.

${ }^{11} \mathrm{~L}$ Chen and $\mathrm{CH}$ van Rhee, 'Introduction' in Chen and van Rhee (n 7$) 3$.

${ }^{12}$ Zhonghua Renmin Gongheguo Minfa Tongze General Principles of Civil Law of the People's Republic of China (1986), Gazette of the State Council of the PRC (1986) 72, 371-92

<http://fgk.chinalaw.gov.cn/article/flk/198604/19860400267347.shtml>.
} 
the aforementioned General Principles of Civil Law (GPCL) passed in 1986. Article 122 dealt with product liability as follows: 'If a substandard product causes property damage or physical injury to others, the manufacturer or seller shall bear civil liability according to law. If the transporter or storekeeper is responsible, the manufacturer or seller shall have the right to demand compensation for its losses.' In conjunction with the Regulations concerning Liability for the Quality of Industrial Products issued in the same year, these rules signified the first attempt to introduce the notion of product liability into modern China. ${ }^{13}$ As no civil recourse had previously been available to dissatisfied consumers, China was essentially constructing a system of product liability from scratch.

The inclusion of product liability in the 1986 GPCL arose from the recognition of the growing needs of the emerging market-based economy and thus represented an ambitious top-down attempt to introduce a tort system capable of supporting further economic reforms; in particular, attempting to reform China's powerful state-owned enterprises by making them accountable for shoddy goods. These initial steps to introducing product liability principles into China were not insignificant, but overall were 'not sufficiently detailed to be applied uniformly by the courts'. ${ }^{14}$ This is clear from the scant detail provided by Article 122 outlined above: how should the manufacturer bear civil liability? What would a claimant need to prove in order to claim? What potential defences would be available to allow a defendant to avoid liability? Without giving any further detail, such a vague provision did not allow for product liability claims to be effectively mounted against manufacturers of defective products by disgruntled consumers.

In addition, the mechanisms provided for enforcing these new product quality standards were almost exclusively limited to public enforcement through state agencies reflecting the

\footnotetext{
${ }^{13}$ For discussion of the origins of tort in China more generally see Lin (n 5).

${ }^{14}$ AJ Green, 'Tort Reform with Chinese Characteristics: Towards a "Harmonious Society" in the People's Republic of China' (2008) 10 San Diego International Law Journal 127.
} 
historical position whereby safety issues had been handled almost exclusively by government bodies. ${ }^{15}$ This reliance on public enforcement mainly through administrative action in China is common in many different areas of law enforcement, but it denied individual consumers any power to directly pursue a manufacturer of defective products. Further, these early attempts at tort regulations, such as the 1986 Regulations concerning Liability for the Quality of Industrial Products, focused on utilizing 'vertically oriented administrative legislation'. ${ }^{16}$ In other words, the power of the individual consumer to initiate an action in court against a negligent manufacturer was minimal. However, this reflected the wider Chinese legal system at that time; the capacity of the courts to deal with civil litigation was limited and mediation firmly remained the preferred approach to resolving civil disputes over defective products. ${ }^{17}$

Thus, consumer rights and the issue of liability for defective products were not tackled more effectively until the promulgation of the Product Quality Law 1993 (PQL) ${ }^{18}$ and the Consumer Rights and Interests Protection Law 1993 (CRIPL). ${ }^{19}$ The 1993 PQL contained the first clear statement of civil liability for defective products: 'A manufacturer shall be liable for compensation if its defective product causes damage to human life or property other than the defective product itself' (Article 41). As such, it was laid down as a key cornerstone of the Chinese product liability system and remains so today. ${ }^{20}$ However, the majority of provisions in the PQL are concerned with administrative control over product quality and how such standards are enforced. Accordingly, the PQL was complemented by the CRIPL which focuses on the rights of individual consumers. For example, CRIPL Article 11

\footnotetext{
15 ibid 123.

${ }^{16}$ Epstein (n 10) 318.

${ }^{17}$ For wider discussion of the Chinese legal system at this time, see SB Lubman, Bird in a Cage: Legal Reform in China after Mao (Stanford University Press 1999).

${ }^{18}$ Zhonghua Renmin Gongheguo Chanpin Zhiliangfa, Law on Product Quality of the People's Republic of China (1993) <http://www.most.gov.cn/eng/policies/regulations/200501/t20050105_18422.htm>.

${ }^{19}$ Zhonghua Renmin Gongheguo Xiaofeizhe Quanyi Baohufa, Law on Protection of Consumer Rights and Interests of the People's Republic of China (1994) <http://fj.baic.gov.cn/shunyi/detail.asp?ID=1560>.

${ }^{20}$ Indeed, Article $41 \mathrm{PQL}$ arguably espouses a clearer product liability principle than the more recent Article 41 TLL as it explicitly includes both property damage and personal injury, a distinction blurred by the TLL which merely refers to 'harm caused to another person'.
} 
provided: 'Consumers suffering from personal injury or property damage resulting from their purchasing or using of commodities or receiving of services shall have the right to demand compensation in accordance with the law.' Although superficially this provision is not farremoved from the previous provision under Article 122 of the 1986 GPCL, by shifting the focus to the right of the consumer to claim, rather than the liability attaching to the manufacturer, the CRIPL marked a significant shift in the foundations of the product liability system. For the first time, the role of individual consumers as important players in the control of defective products was beginning to be recognized.

Taken together, these two laws (the PQL and CRIPL) worked hand-in-hand to establish a codified framework for the regulation of product quality. However, these 'first generation' Chinese tort laws still relied on the traditional model of enforcement primarily through governmental administrative agencies rather than empowering individual consumers to bring negligent manufacturers to court directly. ${ }^{21}$ Even the PQL 1993, which represented a significant step forward towards a comprehensive framework for the regulation of products, still relied on enforced arbitration rather than the courts as the primary method of dispute resolution. ${ }^{22}$ Article 47 mandated that where a civil dispute over product quality arose the parties concerned should first try to reach a settlement through negotiation or mediation. If this fails, arbitration is the next step and filing a suit with the People's court is the final option listed for dispute resolution. Similarly, Article 34 of the CRIPL listed instituting legal proceedings in the People's court as the last of five options provided for dispute resolution available to disgruntled consumers. Thus, litigation was the final option available after less formal means of dispute resolution had failed and arbitration and mediation played a much more significant role in resolving consumer disputes at this time.

\footnotetext{
${ }^{21}$ G Zhao, 'Chinese Product Liability Law: Can China Build Another Great Wall to Protect Its Consumers?' (2002) 1 Washington University Global Studies Law Review 581.

${ }^{22}$ Green (n 14) 129.
} 
Under the PQL and CRIPL, arbitration was to be handled by intermediary bodies such as the China Consumers' Association (CCA), which was founded in 1984 to act as a channel for consumer complaints. It has even been suggested that state-sponsored semi-official consumer organizations such as the CCA play an important role in directing unrest away from the political arena and towards private enterprises. Indeed, it has also been claimed that the Chinese government treats the issue of product quality so seriously because of its perceived potential to bring instability to the country. ${ }^{23}$ As a result, the first generation of tort regulations in China governing liability for defective products relied on state agencies and semi-official bodies such as the CCA to enforce the law rather than empowering individual consumers to litigate against negligent manufacturers, in order to maintain an important element of state control over the issue of product quality. However, this (over-)reliance on state agencies to enforce consumer rights began to change at the start of the twenty-first century with the emergence of a 'second generation' of tort laws which displayed 'a more favourable attitude towards private court actions'. ${ }^{24}$ In the early 2000 s, further laws and regulations were passed which aimed at extending the rights of individual citizens into new areas of liability, as well as the PQL being amended in 2000. For example, the Production Safety Law 2002, Road Traffic Safety Law 2003 and the 2002 Regulations on the Handling of Medical Accidents all provided coverage for new situations where tort liability was emerging. However, these new laws had little or no impact on the product liability regime in China and it was not until the Tort Liability Law (TLL) was passed in 2009 that any significant changes were made.

Initially, the 1986 GPCL were intended to be replaced by a comprehensive civil code. However, this original grandiose aim was abandoned and instead, reforms of the civil laws in

\footnotetext{
${ }^{23}$ WW Shen and IHY Chiu, 'Comparative Analysis of Key Aspects of Product Liability Law in China and the United States' in D Campbell (ed), Liability for Products in a Global Economy (Kluwer Law International 2005) 311 , fn 2.

${ }^{24}$ Green (n 14) 130.
} 
China proceeded via an incremental approach with the passing, for example, of the Contract Law in 1999 and the Property Law in 2007. The civil law reforms reached a zenith with the promulgation of the Tort Liability Law in 2009 following several years of debate. In fact, the first draft of the Tort Liability Law had been released in 2002 for comment. This draft had led to fierce debate about the potential development of the law of tort in China, with rival drafts emerging from various academic scholars, such as the 2002 draft by Professor Zhang Xinbao published in the prestigious journal $\mathrm{Si} \mathrm{Fa}^{25}$ and the draft by Wang Liming of Renmin University published in $2004 .^{26}$ Throughout the next seven years, the academic debate amongst legal scholars in China continued to rage, against a background of increased consumer awareness. ${ }^{27}$ This revolution in the role of the Chinese consumer citizen in the domestic economy could be said to have been driven in part by the state, as stimulating domestic demand is necessary to balance China's economic growth away from the current focus on export-driven growth. It could also be seen as reflecting the official policy goal espoused particularly by former President $\mathrm{Hu}$ Jintao of promoting a 'harmonious society' (hexie shehui), in order to confront rising inequalities and regional disparities in China's overall development and maintain social stability, a key aim of China's central government.

By 2009, the final draft of the Tort Liability Law (TLL) was being prepared for promulgation. The final draft reflected the rise of individual Chinese consumers as well as including pressing issues in contemporary Chinese society such as medical negligence and environmental pollution. In addition, the TLL also demonstrated the receding of the role of the state through various government agencies as the primary enforcement mechanism of

\footnotetext{
${ }^{25}$ XB Zhang, 'China's Draft Civil Code-Tort Liability Chapter: A Suggested Version with Analysis' (2002) 3 Si Fa 14.

${ }^{26}$ LM Wang (ed), Draft Civil Code of China: A Suggested Alternative and Discussion (China Legal System Publishers 2004). All the relevant drafts are outlined and analysed in GW Conk, 'A New Tort Code Emerges in China: An Introduction to the Discussion and a Translation of Chapter 8-Tort Law of the Official Discussion Draft of the Proposed Revised Civil Code' (2007) 30 FordhamIntlLJ 935.

${ }^{27}$ See E Croll, China's New Consumers: Social Development and Domestic Demand (Routledge 2006) for a good overview of the development of the Chinese consumer.
} 
product quality, as private enforcement by individual consumers came to the fore. The TLL thus represented the final major building block in the contemporary product liability system in China. The Tort Liability Law (TLL) was passed by the Standing Committee of the NPC on 26 December 2009 and became effective on 1 July 2010. This was in contrast to the usual legislative process whereby the National People's Congress (NPC) is responsible for passing legislation, with the Standing Committee of the NPC empowered to supplement and amend laws passed by the NPC but only where necessary between NPC sessions. In addition, the TLL was passed only three weeks after the period for public comments on the draft law closed, plainly an insufficient time to fully consider the issues raised by comments.

Clearly, there was some urgency to the final passing of the TLL. Officially, the TLL was passed so urgently because it dealt with issues of great public concern. The relevant NPC Work Report proclaims: 'this law is of great importance for protecting the legitimate rights and interests of civil subjects, preventing and punishing infringements of rights, reducing and resolving conflicts in society, and promoting social harmony and stability'. ${ }^{28}$ Nonetheless, momentum may also have been provided in the wake of the international outcry following incidents such as the Sanlu melamine-tainted milk scandal and the perceived cover-up and suppression of compensation claims from alleged victims. ${ }^{29}$ Several infants died and tens of thousands of others were physically affected by the consumption of infant formula milk which had been adulterated with a chemical called melamine in order to mask the dilution of the milk. The media outcry conceivably led to a speeding-up in the passing of the final TLL.

In this respect, the Chinese experience is similar to the development of the EC Directive. In Europe, pressure towards introducing a strict liability regime for defective products started to build in direct response to the thalidomide disaster, where a drug used in pregnancy led to

\footnotetext{
28 'NPC Work Report 2010' <http://cpcchina.chinadaily.com.cn/news/2011-03/09/content_12144307_3.htm>.

${ }^{29} \mathrm{~S}$ Chen, 'Sham or Shame: Rethinking the China's Milk Powder Scandal from a Legal Perspective' (2009) 12(6) Journal of Risk Research 725-47.
} 
catastrophic unforeseen birth deformities. Similar to opinions in the Chinese media postSanlu milk scandal, there was a palpable sense that the victims had not been adequately protected by the law and thus reforms were necessary in order to protect injured parties in future. ${ }^{30}$ In addition, politicians recognized that the average citizen did not feel engaged with the European Community and consumer protection measures were felt to be a way of giving the Community 'a human face'. ${ }^{31}$ Therefore, the final impetus to promulgating the 2009 TLL in China and the engine driving the drafting of the EC Directive in Europe were fuelled by similar desires to respond to specific product failures. ${ }^{32}$

Conversely, the development of product liability in the US does not seem to have been motivated by one particular scandal involving a defective product. Rather, prior to the 1960s, US courts had been expanding liability for defective products through contractual liability circumventing the doctrine of privity. However, treating such cases as contractual was stretching such principles to breaking point. Thus, the shift in the US to a system based on strict liability in tort occurred with the leading 1963 case of Greenman v Yuba Power Products Inc. ${ }^{33}$ and reinforced by the Restatement (Second) of Torts only two years later, which provided that 'one who sells any product in a defective condition unreasonably dangerous to the user or consumer or to his property is subject to liability for physical harm thereby caused to the ultimate user or consumer, or to his property'. ${ }^{34}$ This broadly worded statement of strict liability was subsequently adopted by many states across the US and arguably led to a product liability crisis by the 1970s and 1980s in which litigation became so commonplace that obtaining insurance became either uneconomic or even impossible for

\footnotetext{
${ }^{30}$ For an overview of the EC Product Liability Directive development and implementation, see P Shears, 'The EU Product Liability Directive-Twenty years on' (2007) JBL 884-908.

${ }^{31}$ G Borrie, The Development of Consumer Law and Policy: Bold Spirits and Timorous Souls (Stevens 1984) 10.

32 J Stapleton, 'Bugs in Anglo-American Products Liability' in Fairgrieve (n 9) 363.

33377 P 2d 897 (1963).

${ }^{34}$ Section 402 A.
} 
some classes of product. ${ }^{35}$ Consequently, the Restatement (Third) of Torts: Product Liability published by the American Law Institute in 1998 could be seen as a retrenchment with strict liability being in effect restricted to manufacturing defects. Thus, the Restatement Second largely arose through top-down pressure for wider legal reform, whereas the Restatement Third conversely dealt with bottom-up pressure to stem the flood of product liability cases. Similarly in China, whilst the first generation of product liability laws arose from top-down political desire to maintain and even stimulate nascent economic reform, the latest amendments to the product liability regime seem to be primarily bottom-up reactions to the negative publicity surrounding the Sanlu milk scandal. However, although the final draft was adopted extremely swiftly, the process of drafting and modifying the TLL had been taking place since the first draft was issued in 2002, so the final law could simply be seen as the culmination of a much longer process. The substantive content of the completed Chinese product liability system will now be considered in more detail.

\section{KEY ELEMENTS OF THE PRODUCT LIABILITY SYSTEM IN COMPARATIVE PERSPECTIVE}

The 2009 TLL itself consists of 12 chapters, including general provisions dealing with issues such as joint liability, contributory negligence and the availability of damages for emotional distress as well as damage to property or personal injury. The structure of the TLL broadly follows the German civil code (BGB) law of delict which distinguishes between grounds of liability and consequences of liability; consequently they are considered in separate chapters in the TLL. In addition, there are several special chapters dealing with the specific issues of product liability, motor vehicle accidents, medical negligence, environmental pollution, liability arising from high-risk circumstances or liability for injury caused by kept animals or things. Liability for defective products is thus a key area of reform within the 2009 TLL and

\footnotetext{
${ }^{35}$ G Howells, Comparative Product Liability (Dartmouth 1993) ch 12.
} 
the provisions relating to product liability specifically will now be considered, in conjunction with the PQL provisions which still form the foundation of the product liability system.

The first issue at the heart of any product liability system is to locate and define the fundamental concepts such as what constitutes a 'product' and what constitutes a 'defect'. Another key issue is to establish the parties who may face civil liability under a product liability system and on what basis their liability may arise. This is particularly pertinent with the spread of strict liability in many other jurisdictions globally. The issue of bases of liability is also clearly linked to the issue of available defences and the remedies which may potentially be awarded to victims injured by defective products. Finally, the mechanisms by which product quality and safety standards are enforced cannot be ignored. Although the majority of this paper discusses civil remedies, the role of the responsible governmental administrative agencies also needs to be briefly considered in order to obtain a fuller picture of the product liability system in China.

\section{A. Fundamental Concepts of Product Liability}

Where can the relevant legal provisions on product liability in China be found? Despite the 2009 TLL being the latest addition to the product liability laws in China, the relevant chapter (Chapter 5) on liability for defective products only contains 7 Articles, so there is a clear need to refer back to previous detailed provisions on product liability. The main source therefore continues to be the 1993 Product Quality Law (PQL) in association with the 1994 Law on the Protection of Consumer Rights and Interests (CRIPL) and related regulations. In this respect, product liability is not dissimilar to many other areas of substantive law in China, in which it is necessary to refer to myriad various laws, implementing regulations as well as relevant judicial interpretations issued by the Supreme People's Court in order to grasp the relevant legal principles. This reflects the incremental development of the legal system in the China 
more generally in the reform and opening-up period since 1978, as China's leaders respond to the needs of the emerging market-based economy and associated needs for laws to regulate this. This measured and considered strategy for reform reflects the idiom most famously associated with former President Deng Xiaoping of 'crossing the river by feeling for stones' (mo shizi guo he). Although this method of legal reform does leave sufficient flexibility to respond to emerging conditions in China as reforms progress, it does leave a great deal of confusion and a lack of transparency about the precise rules in force at any time.

For example, no definition of 'defect' is given in the TLL; Article 46 of the PQL contains the required definition. Interestingly, the test laid out in this Article hazily defines defect as 'the unreasonable danger existing in a product that endangers the safety of human life or other person's property', which draws no distinction between manufacturing defects, design defects and defects in instructions or failure to warn, a categorisation which was introduced in the US by the Restatement (Third) of Torts: Product Liability in $1997 .{ }^{36}$ However, by drawing no distinction between these categories of defect, China is also in line with the majority of other product liability regimes. ${ }^{37}$ The main issue with this definition is the use of the word 'unreasonable' (bu heli de). As there is no further clarification on what level of danger would be permissible in a product or even a list of factors to consider (such as, for example, the type of product; the intended use of the product; the intended audience for the product; any use of warnings), it is difficult to see how this definition can be consistently applied in practice. PQL Article 46 also provides that where there are national or industry standards safeguarding the health or safety of human life and property, 'defect' means inconformity to such standards. Thus, by relying on an undefined standard of reasonableness, the definition of what constitutes a defect in the Chinese system seems to

\footnotetext{
${ }^{36}$ However, this distinction is not always clear-cut: CJ Miller and RS Goldberg, Product Liability (2nd edn, OUP 2004) 23.

${ }^{37}$ M Reimann, 'Liability for Defective Products at the Beginning of the Twenty-First Century: Emergence of a Worldwide Standard?’ (2003) 51(4) AmJCompL 751, 770.
} 
more closely follow the 'consumer expectations' test associated with the EC Directive definition of defect (defined by Article 6 as the safety of the product is not such as a person is entitled to expect) rather than the 'risk-utility' test favoured in the United States. ${ }^{38}$

For another key definition, that of 'product', it is also necessary to look back to the PQL for clarification. In the PQL Article 2(2), 'products' are defined fairly narrowly as things 'processed or manufactured for sale'. Therefore, raw materials and unprocessed goods are explicitly excluded from the product liability provisions. PQL Article 2(3) also explicitly excludes construction projects. This definition is arguably preferable to the much broader definition of product in Article 2 of the EC Product Liability Directive of 'all movables even if incorporated into another movable or into an immovable'. ${ }^{39}$ The definition used in the PQL could be seen as closer to the US definition of product as 'tangible personal property distributed commercially for use or consumption' ${ }^{40}$ By the explicit inclusion of 'for sale' in the Chinese version, it is perhaps drawing upon the same notion that product liability is inextricably linked to the commercial nature of the transaction. Thus, the key concepts of 'product' and 'defect' at the heart of the product liability system in China seem to draw on both the US model as well as the EC Directive, with the concept of 'product' more closely aligned to the US exemplar and the concept of 'defect' closer to the European approach.

\section{B. Bases of Liability}

It is undeniable that the global trend in product liability over the past 30 years has been towards the wider application of strict liability. However, the careful drafting of the bases of liability for potential defendants is critical in ensuring a balance between the consumer's interest in identifying a suitable defendant and claiming compensation and the commercial

\footnotetext{
38 ibid, 767-71.

${ }^{39}$ G Brüggemeier, Modernising Civil Liability Law in Europe, China, Brazil and Russia: Texts and Commentaries (CUP 2011) 188.

40 Third Restatement, section 19.
} 
parties' interest in avoiding unnecessary liability. This can be seen in the retrenchment from the 1965 US Restatement (Second) of Torts section 402A which contained a broadly worded statement of strict liability; consequently, the US Restatement (Third) of Torts: Product Liability restricted the operation of strict liability to commercial parties only. Thus, China needed to take care in drafting the general principles of liability which lie at the foundations of the product liability system.

Whereas under Article 4 of the 1993 Product Quality Law, 'Manufacturers and sellers shall be liable for product quality in accordance with this Law', the scope of potential defendants has now been widened by the 2009 TLL. Broadly speaking, any party in the chain of distribution could now face liability for defective products under the TLL. Article 41 states that 'if injury is caused to another due to a defect in a product, the producer shall bear tort liability'. Note there is no need to prove the producer was at fault; liability under Article 41 is strict. Article 42 states that 'if injury is caused to another due to a product defect that developed as a result of the fault of the seller, the seller shall bear tort liability'. In contrast to Article 41, Article 42 requires that fault liability be proved in order for a seller to be held liable.

However, Article 42 also provides that if the seller is unable to name the producer or supplier of the defective product, the seller shall bear tort liability'. Thus, the seller can also face non-fault liability for the defective product if they are unable to identify the producer or supplier; the aim here is to protect the consumer from the situation whereby they are unable to identify a defendant to bear responsibility. This distinction appears similar to the provisions of the EC Directive whereby the 'producer' of the defective product is the primary defendant (Article 1) but other parties in the distribution chain may face strict liability if they are unable to identify the producer (Article 3(3)). Thus, the Chinese approach seems to mirror the EC Directive rather than the US model under which any commercial party in the 
manufacturing and distribution chain may be liable as the notion of liability flows from the commercial sale of the product, ${ }^{41}$ rather than the specific role of the defendant in that chain.

Article 43 provides that a claimant may choose whether to pursue the producer or the seller for damages and also provides for the producer or seller to seek indemnification from the other if they are at fault. Finally, Article 44 also extends liability to third parties in the chain of distribution such as carriers or warehouse owners. If such a third party is found to be at fault, the producer or seller can seek indemnification from them after compensating the injured party. Therefore, although an injured party cannot claim against a third party in the distribution chain directly, they may still be liable to indemnify the manufacturer or seller if it can be proved that they are responsible for the defect in the product. However, there has been some uncertainty amongst commentators about the precise significance of TLL Article 43. It seems unclear whether Article 43 is intended as a more general statement of liability overriding Articles 41 and 42; by permitting claimants to choose the defendant they wish to pursue, are the manufacturer and distributor really jointly and strictly liable? If this were the case, the TLL would consequently be much closer to the US model of liability. On the other hand, in reality the differences between these two approaches to potential bases of liability amongst defendants in the distribution chain are minimal. ${ }^{42}$ It seems more likely on balance that Article 43 is not intended to act as a more general statement of strict liability; rather the provisions distinguishing between fault and strict liability in the preceding two Articles remain as the main principles of liability. Presuming this to be the case then China seems broadly to be following the European approach, which is also in line with the approach taken to the basis of product liability across the Asia-Pacific region more generally. ${ }^{43}$

\footnotetext{
${ }^{41}$ Third Restatement, section 1.

${ }^{42}$ Reimann (n 37), 765.

${ }^{43}$ D Harland and L Nottage, 'Conclusion: Trends towards Strict Liability and Consumer Product Safety Regulation' in J Kellam (ed), Product Liability in the Asia-Pacific (3rd edn, Federation Press 2009) 559-78.
} 


\section{Available Defences and Remedies}

In terms of burden of proof, China again appears to implement a European-based model whereby the claimant must prove defect, harm and causation (EC Directive Article 4) and the defendant then has the opportunity to show that it is probable that the defect which caused the damage did not exist when the product was put into circulation (EC Directive Article 7(b)). However, in contrast to other jurisdictions in which monetary compensation is the primary outcome of a product liability suit, China offers a range of remedies within which compensation is just one consequence. The other remedies include: cessation of infringement, removal of obstruction, elimination of danger, return of property, restoration to original status, apology, and the elimination of consequences and restoration of reputation (TLL Article 15). Therefore, the overall emphasis of the whole law of tort in China is not solely on providing financial redress to the victim; rather, a parallel purpose is maintaining social harmony. This concept is supported by Article 1 of the 2009 TLL which lays down the purposes of the TLL as: 'to protect the legitimate rights and interests of parties in civil law relationships, to clarify the tort liability, to prevent and punish tortious conduct, and to promote social harmony and stability'.

Turning to potential defences, there are three main defences available to a defendant to a product liability claim in China. Under Article 41 of the PQL 1993, 'a manufacturer shall not be liable for compensation if it can prove the existence of any of the following circumstances: 1) The product has not been put into circulation; 2) The defect causing the damage did not exist when the product was put into circulation; 3) The science and technology at the time the product was put into circulation was at a level incapable of detecting the defect'. Additionally, the definition of 'defect' given in Article 46, 'where there are national or industry standards safeguarding the health or safety of human life and property, "defect" means inconformity to such standards'. Consequently, if a defendant 
manufacturer can prove that the product in question conforms to such standards, this may also act as a potential defence, although it may just be taken as evidence that the product in question is not defective rather than conclusive proof. The inclusion of the so-called 'development risks' defence outlined in PQL Article 41(3) directly emulates the provisions of the EC Directive. Following two draft Directives in 1976 and 1979 which were firmly proconsumer, the final version of the Directive published in 1985 acceded to demands from several Member States that the provisions should be more business-friendly. As a result, the Directive is vaguely worded and despite using the rhetoric of strict liability, undermines this principle with the inclusion of the controversial 'development risks' defence in Article 7(e). Thus, the product liability system again draws on the European approach in terms of available defences.

In terms of recoverable damages, there is an almost complete global consensus that damage to the defective product itself is not recoverable as it is regarded as pure economic loss and China is no exception in this regard. PQL Article 41 is explicit in excluding the defective product itself from the scope of potential liability. In addition, whereas the EC Directive covers both personal injury and property damage over 500 euros, other than the defective product itself (Article 9) and the item of property must fall under the rather vaguely worded 'consumer property' used mainly for private use or consumption, under the Chinese system, no such arbitrary monetary thresholds exist and there is no restriction to the property damage as consumer property. In addition, Article 44 of the PQL, after outlining the damages available for personal injury/death and property damage, also states, 'where the infringed suffers any other serious losses, the infringer shall also compensate for such losses'. This provision consequently seems much more generous than those systems following the EC Directive and potentially closer to the US system which has seen the award of sizable damages to claimants injured by defective products. 
The Chinese system also appears to offer generous rewards to claimants through the controversial inclusion of punitive damages. Although punitive damages did exist in China prior to the passing of the 2009 TLL, they were only available in certain limited situations. For example, under Article 96 of the Food Safety Law 2009, consumers could seek damages of up to ten times the purchase price and under Article 49 of the CRIPL 1994 twice the cost of the goods or services should be refunded in the case of deceptive (fake) products. This socalled 'double compensation' provision under the CRIPL was utilized (and even arguably exploited) by a famous consumer advocate called Wang Hai. He positioned himself as a consumer champion by deliberately purchasing goods which he knew to be fake, then returning them and demanding double the purchase price. He soon shot to fame achieving a celebrity status in China and even set up a consultancy company to expand his fight for consumer rights. ${ }^{44}$ Thus, the provision of punitive damages has not been discussed as an obvious mechanism to benefit consumers as it has been widely condemned as having the potential for misuse.

Nevertheless, the availability of punitive damages has now been expanded to all areas of product liability through Article 47 of the 2009 TLL which provides that 'if a producer or seller has clear knowledge that a product contains a defect but nonetheless continues to produce or sell the same, resulting in the death of another or serious harm to the health of another, the injured person shall have the right to demand commensurate punitive damages'. Thus, the TLL does not offer any further indications of how punitive damages may be calculated, beyond limiting their availability to cases of serious personal injury or death. It is not clear whether the calculation of punitive damages should be linked to the extent of the claimant's injury or to the magnitude of the defendant's behaviour. However, 'Chinese law

\footnotetext{
${ }^{44}$ For more details on the so-called 'Wang Hai phenomenon' see B Hooper, 'The Consumer Citizen in Contemporary China' (2005) Working Paper No 12, Centre for East and South-East Asian Studies, Lund University, Sweden <http://www.ace.lu.se/images/Syd_och_sydostasienstudier/working_papers/Hooper.pdf >
} 
commentators postulate that courts will be reluctant to award more than double the amount of damages resulting from the injury. ${ }^{45}$ Indeed, the draft of the TLL was amended at the final stage to limit the scope of punitive damages due to concerns about excessive compensation potentially being awarded. ${ }^{46}$ There were significant changes between the second draft of the TLL and the final promulgated version. ${ }^{47}$ Article 45 of the second draft stated that if production and sale of a product continues although its defectiveness is known and as a result the life and health of an individual is harmed, the victim is entitled to claim for punitive damages according to the law. However, the final promulgated version of the TLL restricts the award of punitive damages to the more limited circumstances where the victim suffers either serious damage to health or death. This echoes the global trend away from awards of large or excessive punitive damages, particularly in the US over the past ten years. ${ }^{48}$ Therefore, the availability and calculation of punitive damages remains a grey area within the TLL; with no monetary limits specified within Article 47 itself, and no indication of whether mere constructive knowledge would suffice, ${ }^{49}$ close attention should be paid to emerging case law and the latest amendments to relevant laws and regulations to see how these ambiguities are resolved.

\section{Enforcement Mechanisms}

Although individual consumers are now empowered to initiate civil actions against manufacturers of defective products, administrative mechanisms still play a large role in the

\footnotetext{
45 D Wang and C Madaio, 'Navigating China's New Tort Liability Law' (2010) <http://www.milesstockbridge.com/pdfuploads/697_MEEHANCHINAARTICLE.pdf>.

${ }^{46}$ L Cui, 'The Draft Tort Liability Act clarifies the scope of punitive damages' (2009) <http://www.npc.gov.cn/huiyi/cwh/1112/2009-12/23/content_1531722.htm>.

${ }^{47}$ H Koziol and Y Zhu, 'Background and Key Contents of the New Chinese Tort Liability Law' (2010) 1(3) Journal of European Tort Law 328-61, 352.

${ }^{48}$ MA Behrens, GL Fowler and S Kim, 'Global Litigation Trends' (2009) 17(2) Michigan State Journal of International Law, particularly 187-93.

${ }^{49}$ P Neumann and C Ding, 'China's New Tort Law: Dawn of the Product Liability Era' (2010) China Business Review, March-April<http://www.chinabusinessreview.com/chinas-new-tort-law-dawn-of-the-product-liability$\mathrm{era} />$.
} 
enforcement of product quality. The main agency responsible for product quality is the General Administration for Quality Supervision, Inspection and Quarantine (AQSIQ), ${ }^{50}$ which is a ministerial level department reporting directly to the State Council. Subordinate to the central agency are 31 provincial-level Bureaus of Quality and Technical Supervision and vertical responsibilities cascade down to local level Bureaus below this. Most of AQSIQ's powers and responsibilities are drawn from the Product Quality Law, including product quality inspections, standardisation, and enforcement of product recalls. However, the AQSIQ is not the only agency involved in the product liability system; the State Administration of Industry and Commerce (SAIC) also oversees product and safety issues and many other authorities are empowered to handle product safety issues within their own fields, such as the Ministry of Agriculture, Ministry of Health, State Food and Drug Administration for example. ${ }^{51}$ There are several areas of overlap in jurisdiction amongst these various agencies and the degree to which they work together in a coordinated manner is not always clear.

One area in which these authorities, particularly the AQSIQ, play a key role is in the administration of a mandatory product recall. Product recalls are now available as a general remedial measure which should be taken if defects are found to be contained in products already placed on the market under Article 46 of the 2009 TLL which expressly sets out a unified warning and recall system for defective products. Further, failure to implement such a recall in a timely and effective manner, shall lead to the producer or seller facing tort liability. This provision is significant because, although product recalls existed prior to the promulgation of the 2009 TLL, they were for specific categories of products only, rather than as a general measure. However, detailed provisions on how such a recall should be

\footnotetext{
${ }^{50}$ See the General Administration for Quality Supervision, Inspection and Quarantine of PRC homepage for more details regarding its key responsibilities in this field at <http://english.aqsiq.gov.cn/>.

${ }^{51}$ B Li, 'Overview of China's Product Safety Regime' (2010) China Business Review.
} 
implemented are lacking, despite the drafting of the Administrative Rules for the Recall of Defective Products, which were published in April 2009 for consultation. ${ }^{52}$

In addition, Article 45 potentially expands the mandatory product recall system to the situation where a claimant can merely prove that 'a defect in a product jeopardises the safety of another or the safety of the property of another', then they have the 'right to demand that the producer or seller bear tort liability by eliminating the obstruction, eradicating the danger, etc'. Article 45 could possibly be interpreted to mean that any individual could trigger a product recall without even showing a specific injury. This Article is also noteworthy for the mention of property damage; other provisions in the chapter on product liability seem to explicitly require personal injury in order for tort liability to be upheld. In terms of the costs to a manufacturer of a product recall (both in practical financial terms as well as the damage to the brand and/or reputation of the company), ${ }^{53}$ Articles 45 and 46 are highly significant if they foreshadow a more systematic application of mandatory product recalls. However, the vague nature of Article 45 makes it difficult to predict how exactly it may be applied in practice.

Consequently, the issue of product recalls is yet another grey area within the overall Chinese product liability system. However, the CRIPL was amended on 25 October 2013 (with changes effective from 15 March 2014) ${ }^{54}$ and the amendments include Articles which reinforce the product recall provisions under the 2009 TLL. Although no further details are added on the specific operation of such product recall mechanisms, the inclusion of a similar provision in the amended CRIPL reinforces the protection available for consumers. The

\footnotetext{
${ }^{52}$ Gov.cn, 'Office of Legislative Affairs Releases Draft Ordinance on the Management of Defective Product Recalls for Comment' (2009) <http://www.gov.cn/gzdt/2009-04/08/content_1280582.htm>.

${ }^{53}$ Studies have suggested Chinese companies may even suffer higher losses than US companies in the event of a product recall: eg XD Zhao et al, 'The Impact of Product Recall Announcements on Stock Market Reaction: A Study of Chinese Listed Companies’ (2009) University of Indiana Working Paper <http://www.indiana.edu/ rccpb/uschinacooperation/papers/P9\%20Flynn\%20and\%20Zhao.pdf >.

54 'NPC Standing Committee Amend and Revise Consumer Protection Law' (2013) <http://www.npc.gov.cn/npc/xinwen/lfgz/lfdt/2013-10/25/content_1811652.htm>.
} 
amended CRIPL also offers some clarification on the issue of punitive damages discussed above; a defendant found liable in a civil claim for knowingly selling or supplying a defective product which results in death or personal injury could have to pay punitive damages up to two times the damages suffered by the claimant. This is consistent with the predictions made when the TLL provisions on punitive damages were introduced and suggests that the amount of damages will be strictly controlled to avoid excessive punishment of the defendant.

\section{IMPLICATIONS OF CHINESE PRODUCT LIABILITY REFORM AND ENDURING ISSUES}

\section{A. Implications for Legal Reforms in China}

More generally, what do these changes mean for legal reforms in China? By largely completing the civil law framework, the TLL is noteworthy for finishing the huge legislative task undertaken from the passing of the GPCL in 1986 onwards. In addition, the implementation of the TLL can also provide important indicators about the continued preference for mediation over litigation in the civil justice system, the role of the China Consumers' Association (CCA) as a semi-official body channelling disputes away from the formal legal system, the developing of the rule of law in China through capacity-building of legal institutions, as well as the role of law in China in promoting the 'harmonious society' ideal by diffusing potential consumer unrest.

The widely documented historical societal preference for dispute resolution outside of the formal legal system has been continued in the reform era with a 'sustained overall policy emphasis on extrajudicial mediation ${ }^{, 55}$ and this emphasis has certainly been evident in the product liability-related legislation to date with the PQL and CRIPL both mandating mediation as the first dispute resolution method to be undertaken. However, since the second-

\footnotetext{
${ }^{55}$ SB Lubman, 'Dispute Resolution in China after Deng Xiaoping: Mao and Mediation Revisited' (1997) 11(2) Columbia Journal of Asian Law 274.
} 
generation of tort laws began to be promulgated at the turn of the twenty-first century, there has been a marked shift towards more formal dispute settlement through the court system. For example, the 2012 Supreme People's Court Work Report presented in March $2013^{56}$ contained the relevant data for the five years $2008-12$ and stated that the number of civil cases concluded at first instance had increased by 37.8 per cent compared to the equivalent number of cases from 2003-07. Nevertheless, there still appears to be a preference for resolution of consumer disputes outside the formal legal system and indeed, it is doubtful that the court system even has the capacity to deal with all the disputes arising with consumers. Thus, alternative routes to resolve consumer complaints are still meaningful and it will be interesting to see whether the trend of increasing civil litigation continues or stagnates in the future.

This is closely linked to the important role of the China Consumers Association (CCA) in resolving consumer complaints in China, which reflects many wider issues connected to the non-governmental organisation (NGO) sector in China and broader implications for growth of civil society in China. ${ }^{57}$ Although the CCA may at first glance appear to be an independent $\mathrm{NGO}$, in reality it is largely subordinate to the State Administration of Industry and Commerce (SAIC) at both a national and local level, reflecting the murky links between state and semi-official bodies in China. Nevertheless, the CCA does play a hugely significant role in being the initial intermediary dealing with consumer disputes; it handled 665,255 consumer complaints across the country in 2010 according to its own 2010 Annual Report. ${ }^{58}$ Arguably, the CCA also acts as an essential diversion of consumer disputes away from the overburdened court system by promoting dispute resolution through mediation.

\footnotetext{
56 'Supreme People's Court Work Report 2012' (2013) <http://www.chinacourt.org/article/detail/2013/03/id/907830.shtml>.

${ }^{57} \mathrm{~K}$ Yu, 'Civil Society in China: Concepts, Classification and Institutional Environment' in Z Deng, State and Civil Society: The Chinese Perspective (World Scientific Publishing 2011) 63-96.

${ }^{58}$ China Consumers' Association, '2010 China Consumers' Association Annual Report' (2011)

$<$ http://www.cca.org.cn/english/EnNewsShow.jsp?id=341>.
} 
In addition, it is undeniable that 'promotion of consumer welfare in post-Mao China has been closely related to the preservation of the Party-State'. ${ }^{59}$ The issue of consumer rights is therefore intrinsically linked to greater recognition of the rights of an individual in China and also reflects efforts to promote the rule of law in China by entrenching basic expectations for consumers' rights and obligations. ${ }^{60}$ Furthermore, the development of consumer rights can also be seen as an essential element of the stated central aim of developing a 'harmonious society' in China; by offering an outlet for individuals to resolve their discontent, consumer rights can diffuse potential social instability, particularly important to balance the effects of inequitable economic development. Moreover, there are strong indicators such as the aims of the TLL set out in Article 1 that the law of tort is used by the Chinese government as a tool by which they can regulate societal relationships and prevent wider disquiet amongst citizens. This further reinforces the official policy goal of creating a harmonious society and also arguably demonstrates the persistence of an instrumentalist view of the law in China. By using the law as a tool to fulfil policy goals, this could be seen as undermining the development of a wider rule of law, despite the goal of building China into 'a socialist country based on the rule of law' being officially adopted in China by a 1999 constitutional amendment (Article 5). Hence, the TLL has significant implications for the wider Chinese legal system.

\section{B. Implications for Product Liability Systems Globally}

The development of a modern product liability system in China also has important implications for the enforcement of product quality globally. Overall, it would appear that China has chosen to follow the EC Directive rather than the US Third Restatement as the

\footnotetext{
${ }^{59}$ M Palmer, 'The Emergence of Consumer Rights: Legal Protection of the Consumer in the PRC' in K Latham, $\mathrm{S}$ Thompson and J Klein (eds), Consuming China: Approaches to Cultural Change in Contemporary China (Routledge 2006) 77.

${ }^{60} \mathrm{R}$ Peerenboom, The Long March towards the Rule of Law in China (CUP 2002).
} 
preferred model for reform. For example, in defining 'defect', the test chosen is based on consumer expectations rather than risk-utility assessment or by categorizing the defect. The fundamental concept of bases of liability for potential defendants also mirrors the EC approach with manufacturers strictly liable, whereas sellers' liability is fault-based. Most strikingly, the inclusion of the 'development risks' defence appears to be a straight implant from the EC Directive formulation. Nevertheless, there are certain issues where a preference has arguably been shown for the US approach, such as linking the definition of 'product' to the commercial nature of the goods and also in the damages which may be recoverable for a victim of a defective product. By not limiting the damage to 'consumer' property and by allowing for the recovery of punitive damages, the potential awards of damages in China may be larger, mirroring the US where damage awards are typically high.

On balance, China seems to be drawing more closely on the European approach mirroring the conclusions reached by other commentators considering global trends in this field. ${ }^{61}$ The foundations of China's product liability system also seem to echo the findings of a survey of Asia-Pacific countries which found that the European product liability system was the central model for reform, with the US viewed as an outlier. ${ }^{62}$ China is thus converging with regional norms in this field, as well as being broadly in line with global trends. Examining product liability norms from a regional perspective also highlights the relative futility of dividing the relevant jurisdictions into civil law and common law 'families'; in the product liability arena, these distinctions are not useful as there is a great deal of consensus around fundamental norms. What is not clear, however, is to what extent

\footnotetext{
${ }^{61}$ M Reimann, 'Product Liability in a Global Context: The Hollow Victory of the European Model' (2003) 11(2) European Review of Private Law 128-54.

${ }^{62} \mathrm{~J}$ Kellam and L Nottage, 'Europeanisation of Product Liability in the Asia-Pacific Region: A Preliminary Empirical Benchmark' (2008) 31 Journal of Consumer Policy 217-41.
} 
such convergence can be attributed to a conscious duplication of foreign models or whether it is due to a reflection of wider universal norms in tort law. ${ }^{63}$

On the other hand, there are many features of the Chinese product liability system which originate in neither the European nor the US model, but rather have evolved due to uniquely Chinese conditions. An instance of this can be found in the remedies available to victims of defective products, not only the inclusion of a range of remedies not limited to monetary compensation, but also the standard of punitive damages as twice the damages suffered, which appears to be the consistent measure used from the CRIPL 1993 until today. In addition, the overall incremental reform strategy of 'crossing the river by feeling for stones' has proved a necessary approach to learn from experience and slowly mould the legal system accordingly. Although this gradual approach could be criticized for limiting the pace of reforms, the legal system could not have coped with a sudden influx of hundreds of thousands of disgruntled consumers at the start of the reform process when there were only a few thousand lawyers in the entire country. ${ }^{64}$ Thus, it has proved a useful strategy for the reform of the overall legal system in China by allowing time for capacity to grow before expanding the rights of individual claimants to litigate in the courts. Even so, informal dispute resolution methods such as mediation continue to play an important role in resolving consumer disputes for well-documented cultural reasons ${ }^{65}$ and this preference is unlikely to disappear in the short term. These local adjustments to the imported product liability norms provide an interesting example to add to the growing body of case studies which examine how legal transplants have worked in practice rather than maintaining the previous binary

\footnotetext{
${ }^{63}$ S Levmore, 'Rethinking Comparative Law: Variety and Uniformity in Ancient and Modern Tort Law' (1986) 61 TulLRev 235.

${ }^{64}$ R Peerenboom, 'Law Enforcement and the Legal Profession in China' in JF Chen, YW Li and JM Otto (eds), Implementation of Law in the People's Republic of China (Martinus Nijhoff 2002) 125, 130.

${ }^{65}$ See eg BKY Wong, 'Traditional Chinese Philosophy and Dispute Resolution' (2000) 30 HKLJ 304-19.
} 
approach to the debate. ${ }^{66}$ Furthermore, such peculiarly Chinese features suggest that complete harmonization in product liability norms is neither possible nor even desirable as difference in the wider legal system and prevailing legal culture cannot be ignored.

\section{Enduring Issues with Product Liability in China}

Even though recent changes to China's product liability system have brought the system up to a comparable standard with other countries both regionally and globally, these laws on paper are meaningless if consumers do not exercise the rights afforded to them. There are enduring barriers to the effective implementation of the product liability system in China which are both practical and political. Firstly, it is undeniable that many Chinese consumers never even file a claim for defective products due to a combination of factors. It has been suggested that the level of rights-consciousness is low amongst Chinese citizens and that Chinese culture has an innate disdain for conflict. ${ }^{67}$ It is difficult to assess to what extent these cultural factors restrain consumer claims, but it is true to state that the level of damages awarded is low and the legal fees relatively high in comparison. ${ }^{68}$ However, such a low number of claims brought under product liability laws can also be observed in many other jurisdictions ${ }^{69}$ and so this is not necessarily indicative of a dysfunctional system overall.

In terms of practical issues with product quality and safety standards in China, the huge size of the country is clearly an impediment to consistent and efficient enforcement. Enforcement is necessarily decentralized down to a local level but this delegation can consequently become entangled in the thorny issue of local protectionism. In other words, the

\footnotetext{
${ }^{66}$ M Chen-Wishart, 'Legal Transplant and Undue Influence: Lost in Translation or a Working Misunderstanding' (2013) 62(1) ICLQ 1, 3.

${ }^{67}$ For a discussion of 'rights-consciousness' versus 'rules consciousness', see EJ Perry, 'Chinese Conceptions of "Rights”: From Mencius to Mao- and Now' (2008) 6(1) Perspectives on Politics 37-50.

${ }^{68}$ EA Hunt, 'Made in China: Who Bears the Loss and Why' (2009) 27(3) Penn State International Law Review 915, 920.

${ }^{69}$ For Europe, see Lovells, 'Product Liability in the European Union: A Report for the European Commission' (2003) <http://ec.europa.eu/enterprise/policies/single-market-goods/files/goods/docs/liability/studies/lovellsstudy_en.pdf $>$. For similar findings in the Asia-Pacific, see Kellam and Nottage (n 62).
} 
manufacturers responsible for the production of defective products may become so engrained in the local economy that local enforcement bureaus can be reluctant to tackle them for fear of damaging the area economically. A further barrier to effective enforcement can be interagency competition rather than cooperation; with opaque boundaries to each agency's jurisdiction, each rival agency is competing to secure their authority in a particular area or product. This maze of bureaucracy is not unique to China, nor is it unique to the product liability field, ${ }^{70}$ but it does provide an enduring barrier to effective enforcement.

Another issue arising from the sheer size of both the country and the Chinese economy is the difficulties with testing products. In the mid-1990s, some local governments granted exemptions from testing to those companies whose products had previously undergone both national and local level checks. Although these exemptions were abolished in 1997, the system was reactivated by AQSIQ in 2000 in response to complaints from many companies about the burden of inspection. ${ }^{71}$ However, this system unravelled in the wake of the various product scandals of $2007-08$ and is clearly inadequate to protect consumers from defective products. The creation of such an exemption system does nevertheless suggest that the necessary institutional capacity to oversee the entire Chinese product safety and quality system may be lacking.

In terms of political concerns, product liability may also raise several important issues. Product quality is necessary for continued economic growth, but central policy priorities have now shifted away from encouraging growth at breakneck speed towards a more balanced approach considering the impact of economic growth on rising inequalities in Chinese society. Product liability is crucial in this context not only because of the potential for maintaining social harmony, but also because increased levels of product safety and product quality will be necessary in order to build consumer confidence in Chinese products, both

\footnotetext{
${ }^{70}$ For example, these issues of bureaucratic tangles are explored in the field of intellectual property rights: AC Mertha, The Politics of Piracy: Intellectual Property in Contemporary China (Cornell University Press 2005).

${ }^{71}$ Chen (n 29) 737.
} 
domestically and abroad. Consumers are a key constituency for the Chinese government as China's middle class emerges further and scandals such as the Sanlu tainted milk episode need to be avoided in order to maintain societal harmony and ensure the continued dominance of the Chinese Communist Party (CCP).

\section{CONCLUSION}

Following the TLL 2009 coming into force in 2010, the product liability system in China is now largely completed. The development of this system has been underway since the commencement of the reform and opening-up period and has presented many challenges to the Chinese legal system. Taken as a whole, the TLL brings the rights of individuals to the fore, particularly when compared to previous laws such as the PQL and CRIPL which emphasized the role of state agencies to enforce the law or of third-party intermediary bodies such as the CCA to mediate between individual consumers and companies, with litigation seen very much as a last resort. In contrast, the TLL places civil litigation firmly at the heart of the law of tort in China. It could be argued that the TLL does not make radical changes; in many respects, it merely brings together provisions which were previously scattered throughout various laws and regulations such as the PQL and CRIPL. However, by consolidating these diverse provisions together within a centralized statute, the law is more transparent and thus more accessible for individuals to be aware of their tortious rights and obligations.

On the other hand, the TLL does not replace the existing laws and regulations; by providing a general framework on tort liability, there is still a palpable need to refer back to existing laws for detailed provisions. With regard to many of the main changes wrought by the TLL to the product liability system in China, it remains to be seen exactly how these new provisions will be implemented in practice. Indeed, observers noted that as of early 2011, the 
new TLL was yet to be widely implemented..$^{72}$ Thus, particularly with regard to punitive damages and product recalls, close attention must be made to this area in future as the law and its implementation evolve further.

Overall, China's product liability system provides an interesting case study to enrich the study of global trends and norms in this area. In line with many other countries, particularly in the Asia-Pacific region, China's main influence has been the EC Directive rather than the US model. Nevertheless, the Chinese system is not a wholesale transplant of the European system as it still contains aspects more closely aligned to the US approach. More importantly, there are several aspects to the Chinese system which appear to be more uniquely Chinese and actually potentially point to more successful enforcement of the product liability rules if the imported norms have been blended with the local legal culture. On the other hand, even if the substantive rules match up to emerging global norms of product liability, there remain important differences in procedural rules and access to justice. Therefore, caution must remain in evaluating the Chinese product liability system against global standards and close attention must be paid to how the system is applied in practice.

\footnotetext{
${ }^{72}$ Legal Daily, 'Tort Liability Law Impact after 6 Months is Not Large' (2011)

<http://www.legaldaily.com.cn/index_Article/content/2011-01/06/content_2429044.htm?node=5955>.
} 